\title{
ZASTOSOWANIE FACEBOOKA W PRACY ZE STUDENTAMI. REFLEKSJE DOTYCZACE WYKORZYSTANIA SERWISU W PRAKTYCE DYDAKTYCZNEJ
}

\section{Abstract \\ USING FACEBOOK TO WORK WITH STUDENTS - CASE STUDY}

The author describes several years of experience in teaching student groups and describes the role that Facebook can play when working with students. He highlights its importance in communication and mobile education. In the conclusion the author points out that the most important function of Facebook is to inform the academic community about the organization activities, current events and integrate the group when one is its supervisor. The educational functions of Facebook only complement traditional classes and works hops held in lecture halls.

Key words: Facebook, students' education, higher education, communication, communication with students

\section{Wstęp}

Doktor Michalina Rutka w jednym ze swoich tekstów zapytała między innymi, czy Facebook może pełnić funkcję edukacyjną oraz czy polscy uczniowie i nauczyciele są na to otwarci i gotowi [Rutka 2014, s. 145-166]. W wielu artykułach możemy przeczytać o próbach wykorzystania Facebooka do celów edukacyjnych. W jednym z nich autorzy wskazują, że dzięki Facebookowi wzrasta komunikacja między uczniami oraz między nimi a nauczycielami. Ten wzrost komunikacji może mieć pozytywny wpływ na dyskusje, zaangażowanie uczniów i ich integrację. Facebook może być wykorzystany do tworzenia nowych modeli współpracy i funkcjonowania społeczności uczących się i uczonych. Może również wzmacniać proces ucze- 
nia się poprzez dzielenie się różnego rodzaju materiałami edukacyjnymi [Arteaga Sánchez, Cortijo, Javed 2014, s. 138-149]. Historia założyciela Facebooka, Marka Zuckerberga, pokazuje, że chciał on przede wszystkim ułatwić wzajemne kontakty między studentami na Harvardzie, umożliwić dzielenie się materiałami i zdjęciami.

Kiedy w 2012 roku zaczynałem pracę na uniwersytecie, zastanawiałem się, jak usprawnić komunikację w grupie, efektywniej współpracować ze studentami, przekazywać im wiedzę i niezbędne materiały; jak wreszcie realizować skutecznie zadania opiekuna roku. Głowiłem się również nad tym, na ile tezy o roli edukacyjnej Facebooka są prawdziwe i jaką funkcję może on pełnić w środowisku akademickim. Od tego czasu założyłem na Facebooku i prowadziłem kilka grup studenckich. W 2012 roku wykładowcy, z którymi rozpocząłem współpracę, takich grup nie zakładali. Był to więc pewnego rodzaju eksperyment. W niniejszym tekście chciałbym podzielić się kilkuletnimi wnioskami płynącymi z tego przedsięwzięcia i nakreślić strategię [Asterhan, Rosenberg 2015, s. 146) postępowania na Facebooku w pracy i kontaktach ze studentami.

Na potrzeby tego artykułu opisano, jak wygląda założenie i prowadzenie grupy studenckiej przez nauczyciela akademickiego. Analizie poddano treści pięciu grup studenckich funkcjonujących w latach 2012-2015 i administrowanych przez autora tekstu. W skład analizy weszły między innymi posty, komentarze, zdjęcia, ankiety, a także profile członków grupy. Na ich podstawie zaprezentowano mechanizmy wytwarzające się w trakcie funkcjonowania grup, dzięki którym możliwe było opisanie roli, jaką pełni czy może pełnić Facebook w pracy ze studentami. W sumie w grupach znalazło się ponad 150 osób, z czego aktywność wykazywała niewiele ponad połowa ich członków. Uwzględniono również bezpośrednią komunikację między wykładowcą a studentem poprzez aplikację Messenger.

\section{Założenie grupy}

Jeśli zakłada się grupę studencką, ale nie zamierza się interesować studentami, to popełnia się duży błąd. I nie chodzi tu o ich życie prywatne. Chodzi o dwie kwestie. Pierwsza to ich obecność na uczelni - wspieranie w rozwiązywaniu bieżących problemów, tłumaczenie zawiłości administracyjnych, wyjaśnianie wątpliwości, wysłuchiwanie skarg i zażaleń. Zwłaszcza w tej ostatniej kwestii grupa jest miejscem często niekończących się pretensji. Druga sprawa to dostrzeżenie, że student to nie tylko anonimowa osoba, której imienia się nie pamięta i wystawia mu się trójkę. Studenci są mile zaskoczeni, kiedy prowadzący na pierwszych czy drugich zajęciach wie, kim są. Analiza ich profili na Facebooku pozwala kojarzyć twarze z imionami, a także dostrzec w studencie człowieka, który ma swoje pasje i pragnienia.

Jeśli student pracuje w internetowym radiu, warto posłuchać jego audycji; jeśli prowadzi bloga - poczytać go; jeśli jest autorem ciekawych zdjęć - obejrzeć je. Student, jak każdy z nas, potrzebuje dostrzeżenia go, zauważenia i docenienia tego, 
co robi. Potrzeba uznania wśród studentów jest ogromna. Mam wrażenie, że praca studentów najczęściej jest dość mocno krytykowana (pewnie w wielu aspektach słusznie), a ich pasje pomijane. Facebook poprzez profile studenckie, komentarze, posty pozwala dostrzec i wydobyć studenckie zainteresowania związane $\mathrm{z}$ ich kierunkiem studiów, a być może potencjalnym zawodem. Daje możliwość wykorzystania tych pasji na zajęciach, seminariach czy spotkaniach i w ten sposób ich twórczego rozwijania. Zauważam też, że Facebook likwiduje naturalne lęki u osób, które się nie udzielają lub krępują. Grupa pozwala je otworzyć i zaktywizować. Studenci chętniej też dzielą się swoimi problemami na Facebooku [Asterhan, Rosenberg 2015, s. 145], a w moim przypadku zwłaszcza poprzez Messengera.

Mam wrażenie, że Facebook staje się obecnie nieco teatralny, powierzchowny, traci na autentyczności. Sporo jest tu gry pozorów, działań marketingowych. W przypadku zamkniętej grupy autentyczność można zachować. Warto wówczas pamiętać, że grupa jest pewnym intymnym spotkaniem. Studenci wiedzą, że pracodawcy i wykładowcy sprawdzają ich poprzez Google i Facebooka, znają też sposoby, jak się przed tym bronić (sporo można ukryć). Studenci mają świadomość, że to, co napisali, może być użyte przeciwko nim. Jeśli jednak wykładowca kiedykolwiek by się tego dopuścił, oznaczałoby to kres jego działalności na Facebooku w pracy ze studentami.

Na pierwszych zajęciach stosowałem swoisty „facebookowy szantaż”, któremu niemal wszyscy bez protestu się podporządkowywali. Zakładałem zamkniętą "grupę zajęciową/przedmiotową". W ciągu 10 minut było po wszystkim - grupa istniała, miała swoich członków, nazwę i znak, który symbolizował spotkanie. $Z$ reguły jedna lub dwie osoby mówiły, że nie posiadają i nie zamierzają posiadać konta na Facebooku. Szanując ich decyzję, prosiłem jednak, by dowiadywali się na bieżąco od kolegów i koleżanek, co w trawie piszczy. Sam byłem dostępny on-line, na konsultacjach, pod e-mailem, zadania wyznaczałem również po zajęciach. Teoretycznie bez Facebooka można się obejść. Michalina Rutka pisze jednak, że brak konta na Facebooku wiąże się z wykluczeniem z dyskursu publicznego [Rutka 2014, s. 147]. W moim przypadku mogło się to wiązać z częściowym wykluczeniem z zajęć, czyli z dyskursu edukacyjnego. Starałem się pilnować, by do tego nie doszło. Jednak Facebook ma ogromną zaletę - bardzo dobrze organizuje życie zbiorowe grupy. Powstaje ważne pytanie: czy taki szantaż można uznać za uzasadniony? Odpowiedź może wydać się kontrowersyjna. W przypadku studentów dziennikarstwa, o których piszę (a to ważne uszczegółowienie), zdaje się, że tak właśnie jest. Studenci dziennikarstwa - przyszli pracownicy świata mediów i PR - chcąc nie chcąc, muszą wiedzieć, co dzieje się w cyfrowym świecie. Nie ma od tego odwrotu. Ceną za bycie dziennikarzem jest obecność na Facebooku. Czy mój szantaż okazał się skuteczny? Tak, bowiem pod koniec semestru (a zajęcia prowadzę na początku z pierwszym rokiem) konto na Facebooku mieli już wszyscy studenci z grupy. Grupa stała się miejscem wirtualnych spotkań w różnych celach. 


\section{Rola Facebooka w komunikacji ze studentami}

Jedną z największych zalet Facebooka w połączeniu z Messengerem jest ogromna skuteczność komunikacyjna w porozumiewaniu się z grupą studencką. W niektórych kwestiach uniwersytet hołduje archaicznym formom organizacji. Kiedy wykładowcy nie ma wskutek choroby lub innego wypadku losowego, sekretariat wywiesza na drzwiach lub na stronie internetowej kierunku informację o odwołaniu zajęć. Na niektórych uczelniach (zwłaszcza prywatnych) studenci poprzez esemesa dowiadują się o odwołaniu zajęć, ale i to zwykle działa z opóźnieniem. Grupa na Facebooku pozwala odwrócić i skrócić ten proces. Student bardzo szybko otrzymuje informację o odwołaniu zajęć. Może dostać ją wieczorem, dzień przed lub nawet kilka dni wcześniej od samego wykładowcy, a w przypadku zdarzeń losowych dziejących się w weekendy - tuż przed zajęciami. Pozwala to wyjaśnić, dlaczego wykładowcy nie ma, i że wcale nie zapomniał o tym, iż ma zajęcia w niedzielę. Za pośrednictwem Facebooka można sprawnie uzgodnić, kiedy i w jaki sposób odrabiamy zajęcia. Minimalizuje on więc marnotrawienie czasu. Wszystko to pozwala studentowi na jego efektywniejsze wykorzystanie w nauce lub w pracy. Optymalizacja czasu akademickiego życia jest bardzo ważna, a wszelkie próby czynione w tej materii przez prowadzącego są doceniane przez studentów.

Podobnie zorganizowane są dyżury akademickie. W ciągu tygodnia wykładowcy są zobowiązani prowadzić konsultacje w swoim pokoju przez półtorej godziny. W 95\% przypadków spędzają je samotnie, chyba że trwa sesja lub studenci nadrabiają zaległości czy nieprzygotowanie do zajęć. Wszyscy spotykamy się też z dwoma problemami. Termin dyżurów nie zawsze każdemu odpowiada. Kiedy dyżur odbywa się w godzinach przedpołudniowych, studiujący dziennie mają w tym czasie zajęcia, a studenci zaoczni najczęściej pracują. Żeby przyjść na dyżur, musieliby opuścić swoje zajęcia dydaktyczne (które pewnie w związku z tym będą musieli odrobić) lub w przypadku studentów zaocznych zwolnić się z pracy, ewentualnie wziąć urlop bądź przyjechać na dyżur wiele kilometrów. Zastanówmy się, jak reagujemy, gdy musimy pójść do urzędu o 11.00 i marnujemy na to nasz urlop. Podobnie reagują studenci. $Z$ kolei gdy dyżur jest po południu, studenci dzienni mają dodatkowe zajęcia lub pracują i nie bardzo chcą albo nie mają możliwości przyjść na niego. Podobnie wykładowcy. W ten sposób koło się zamyka. Facebook poprzez grupę zajęciową lub aplikację Messenger umożliwia racjonalizację i indywidualizację procesu konsultacji. Można mówić o tzw. mobilnych konsultacjach czy komunikacji mobilnej. Student pyta, dyskutuje, wykładowca zaś odpowiada. Rozmowa może trwać pół dnia z wielokrotnymi przerwami. Nie wszystko da się jednak wyjaśnić za pośrednictwem mobilnej komunikacji pisanej. Jeśli jest pilna potrzeba rozmowy, można darmowo rozmawiać przez Messengera, nie znając numeru telefonu wykładowcy. Warunek: trzeba się na Facebooku „polubić”. Co ważne, studenci dzwonią wyjątkowo rzadko, szanując prywatność wykładowcy, i najczęściej czynią to za jego przyzwoleniem. 
W moim przypadku Facebook wydłużył lub nawet zastąpił dyżur (choć i tak spełniam obowiązek dyżurowania w pokoju). Czy poświęcam na to zdecydowanie więcej czasu niż na dyżurowanie? Tak, ale się na to godzę w imię indywidualizacji procesu dydaktycznego i organizacyjnego, zarówno studenta, jak i mojego. Jest to dla mnie wygodniejsze i przyjemniejsze. A jeśli ktoś chce się ze mną umówić na rozmowę, czynimy to zwykle indywidualnie. I tak podczas dyżuru często jestem aktywny właśnie na Facebooku.

Wiele problemów nastręcza również funkcja opiekuna roku. Od kilku lat rośnie znaczenie i ilość zadań nakładanych na opiekunów, a ujmowanych przez władze akademickie $w$ formalne dokumenty. Opiekunowie nie są jednak gratyfikowani za swoje działania i nie mają narzędzi do pełnienia tej ważnej funkcji. Nierzadko nie mają $\mathrm{w}$ ogóle zajęć $\mathrm{z}$ grupą i tak naprawdę nie mogą jej poznać. Plany opiekunów nie są skorelowane z planami roku, którym mają się opiekować. Zdarza się, że opiekun jest studentom w ogóle nieznany. Facebook pozwala to zmienić. To swoisty pas transmisyjny, który umożliwia stały kontakt z grupą oraz podejmowanie działań o charakterze integracyjnym - wspólnych spotkań, wyjść czy wyjazdów. Jest miejscem dyskusji i rozwiązywania bieżących problemów danego roku na uczelni.

Aby być skutecznym komunikacyjnie, należy jednak reagować jak najszybciej, powiedziałbym nawet - błyskawicznie. Pokazuje to, że jest się nieustannie w gotowości komunikacyjnej z grupą czy całym rokiem studentów. Jeśli tak będzie, grupa na Facebooku odwdzięczy się tym samym. Jeśli natomiast zbyt rzadko reaguje się na to, co dzieje się w grupie, albo nie podtrzymuje się komunikacji, grupa zapadnie w stan hibernacji lub stanie się nudnym miejscem suchych postów informacyjnych bez komentarzy czy dyskusji.

Facebook w połączeniu z Messengerem daje nieograniczone możliwości komunikacji dwukierunkowej: dotarcia wykładowcy do studenta, jak również studenta do wykładowcy. Na Facebooku widać, kto, co i kiedy przeczytał, a kto tego nie zrobił. Można potem dociekać, w czym tkwił problem. Wiadomo zatem, że informacja dotarła do wszystkich, co jest kluczem do sukcesu w budowaniu relacji i porozumienia. Zauważam ważną tendencję - im młodsi studenci, tym więcej „lajkują", a ponadto szybciej i z reguły wszyscy odczytują przesyłane im komunikaty. W starszych rocznikach nie jest to regułą. W komunikacji posty grupowe na tzw. wallu zaczyna też wypierać bezpośrednia komunikacja poprzez wysyłanie wiadomości do członków grupy lub za pośrednictwem aplikacji Messenger. Mam wrażenie, że ważniejsza od komunikacji grupowej staje się indywidualizacja kontaktów.

Od kilku lat rośnie zjawisko zwane „lubię to”. Coraz więcej komentarzy zamieszczanych w grupie przedmiotowej, w tym również moje, jest obiektem „lajkowania”. Najwięcej polubień mają dwie kategorie postów. Po pierwsze, te odwołujące się do emocji grupy - wspierające, dziękujące, żegnające, będące swoistą przechowalnią wspólnej pamięci, albo te będące wynikiem głębokiego rozgoryczenia, zawodu; krótkie wiersze czy formy liryczne. Drugą kategorią jest dowcip, tak zwany „dobry suchar”, jeden-dwa w semestrze, nie częściej. Musi być wyrafinowany 
i przemyślany, odnosić się najlepiej do tego, co dzieje się w świecie medialnym. Podam przykład, zamieszczony zaraz po wyborach samorządowych w 2014 roku (ilość polubień 70\%):

Przychodzi przewodniczący Państwowej Komisji Wyborczej do psychiatry.

- Co panu dolega? - pyta specjalista.

- Prześladuja mnie głosy - odpowiada przewodniczacy.

- Ale jakie głosy?

- Nieważne...

Trzecią kategorią najbardziej lubianych postów są informacje o godzinach dziekańskich czy rektorskich. Zwłaszcza że Facebook umożliwia poinformowanie o nich bardzo szybko, zanim studenci odnajdą szczegóły na uczelnianej stronie internetowej.

Studenci nie lubią spamowania, czyli wszystkiego, co nie dotyczy bezpośrednio grupy. Jeśli chce się na coś zaprosić czy coś polecić, a nie jest to związane z życiem na uczelni i zajęciami oraz organizacją grupy, „lajków” i komentarzy nie będzie, można natomiast wyczuć niechęć. Należy zachować choćby pozorny związek $\mathrm{z}$ tym, co dzieje się w grupie. Podobnie jak z „dobrym sucharem”, można sobie na to pozwolić raz czy dwa, ale na specjalny efekt nie należy liczyć.

\section{Netykieta}

W facebookowej grupie studenckiej czy w komunikacji prowadzonej za pośrednictwem Messengera przekraczanie granic jest i nie jest mile widziane. Grupa jest swoistym polem, na którym strony określają wzajemne relacje. Wykładowca ma oczywiście przewagę, gdyż może pewne komentarze, spekulacje czy zachowania szybko ucinać. Jednak balansuje na krawędzi: jeśli przesadzi w jedną stronę, grupa stanie się wyłącznie miejscem postów informacyjnych, jeśli zaś przesadzi $\mathrm{w}$ drugą stronę i rozbudzi emocje grupy, jego głównym zajęciem podczas semestru będzie obsługiwanie facebookowej dyskusji w wirtualnym świecie.

Głównym problemem w komunikacji za pośrednictwem Facebooka jest potencjalna dostępność. Nie ma znaczenia, gdzie się jest i która jest godzina. Jeśli się odczytuje i odpisuje, dopuszcza się przekroczenie granicy, jaką jest niedzielny wypoczynek czy zwyczajowa cisza nocna. Niektórych może to szokować, ale tuż przed złożeniem pracy licencjackiej i jej obroną rozmowa ze studentami na temat ich studiów może się odbywać nawet po 24.00. Podobnie zresztą jak wysyłanie e-maili. Jeśli do tego dojdzie, studenci będą to bezwzględnie wykorzystywać. Zawsze można przestać odpowiadać, ale warto dać sygnał, że się przestaje, gdyż ktoś po drugiej stronie przesadził. Zaskakująco szybko zostanie to uszanowane.

Kolejną kwestią jest język. Nie wyobrażam sobie, żebym zwracał się do studentów w grupie per Pan/Pani (podobną zasadą kieruję się w codziennych kontaktach). 
Jestem z nimi po imieniu, a oni ze mną nie - i to jest jedyna granica, której przekroczenia nie dopuszczam (chyba że ktoś się na to nie zgadza i zostajemy na Pan/ Pani). Nie obrażam się jednak, gdy ktoś powie do mnie „panie doktorze” albo „psorze”, lub też użyje innej poufałej formy. Facebook sprzyja spoufaleniu się. Hierarchiczne zależności o charakterze feudalnym tutaj nie obowiązują. Podobnie zresztą jest ze zwrotami grzecznościowymi. Obecnie trwa wielka dyskusja na temat zwrotów i form grzecznościowych, na przykład słowa „witam” pisanego w e-mailach. Facebook skraca dystans i komunikację, ale też sprzyja likwidacji tych zwrotów i form. Jeśli komuś to przeszkadza, może z tym walczyć. Mnie to nie razi, nie walczę z tym i poddaję się temu. Przy ogromnej liczbie postów, komentarzy i wiadomości wysłanych przez Messengera pewnie można w ten sposób zaoszczędzić kilka godzin życia, choć wydaje się, że chodzi też o coś innego. Jeśli jest się użytkownikiem grupy, nie przychodzi się do niej i nie odchodzi (dopiero gdy zakończymy naszą współpracę, ale wtedy grupa ulega hibernacji lub likwidacji). Nie mówi się nieustannie „dzień dobry” i „do widzenia”. Po prostu się „jest w grupie”. Brak tych formuł i zwrotów pokazuje gotowość członków grupy do nieustannej interakcji. Co ciekawe, to wszystko nie powoduje zanikania form i zwrotów grzecznościowych, kiedy spotykamy się w realu, a wręcz przeciwnie. Mam wrażenie, że gdy wieczorem konferujemy w cyfrowym świecie, studenci dużo chętniej i z uśmiechem mówią mi rano „dzień dobry”.

\section{Rola Facebooka w procesie organizowania}

Jak już wspomniałem, Facebook znakomicie ułatwia organizację zajęć i wszelkie działania o charakterze logistycznym. Nazwałbym to mobilnością organizacyjną grupy przedmiotowej czy danego roku. Serwis daje jeszcze kilka innych możliwości. Na uczelni zajęcia należy odrabiać. Na Facebooku można swobodnie umówić się na odrabianie, uzgodnić termin, miejsce i znów nie trzeba do tego oficjalnych informacji na stronie kierunku czy w sekretariacie (choć obowiązek ten czynię). Zajęcia można także odrobić bezpośrednio w serwisie. Zamieszczamy wówczas tekst, mamy możliwość dyskusji, przeprowadzenia ankiety, możemy wysłać pytanie z prośbą o odpowiedź lub przygotowanie dla grupy prezentacji etc. Możemy potem sprawdzić wiedzę i umiejętności nabyte podczas odrabiania. Sposobów jest wiele.

Na Facebooku można również błyskawicznie przenieść i przearanżować zajęcia. Podam przykład: mieliśmy zaplanowany dodatkowy wykład. Przyszło mało osób, nałożył się egzamin, który miałem z inną grupą. Odwołaliśmy spotkanie i udaliśmy się w inne miejsce, gdzie zrobiliśmy powtórkę do egzaminu. W międzyczasie spóźnieni dotarli na wykład, ale nas już nie było - byliśmy w innej sali. Szybko napisaliśmy na Facebooku, gdzie jesteśmy, a spóźnieni udali się w nowe miejsce. Ci, którzy nie wybierali się na wykład, bo się uczyli do egzaminu, dowiedziawszy się o zmianie formuły, zjawili się na spotkaniu. To Facebook i związany z nim Messenger był pierwszym drogowskazem. 
Facebook jest także nieoceniony przy okazji organizowania wszelkiego rodzaju wycieczek, wyjazdów studyjnych czy wyjść grupowych. Można rozmawiać o programie, jego szczegółach, szukać wspólnie noclegu, wieczornego wyjścia (kino, teatr), pokazywać mapy, linkować całość, uzgadniać, co, komu i gdzie zamawiamy, dyskutować, głosować etc. Podczas samego wyjazdu studenci są aktywni w grupie: szukamy się, odnajdujemy, kierowca wie, kogo, gdzie ma zabrać. Poprzez dzielenie się wszystkimi troskami związanymi z organizacją wyjazdu czy wyjścia grupa aktywnie we wszystkim współuczestniczy. Pojawiają się propozycje i komentarze, pod wpływem których dokonuje się modyfikacji. Wykładowca-organizator liczy się ze zdaniem studentów i uwzględnia je. To dla nich przecież organizuje pewne przedsięwzięcia. Studenci stają się współorganizatorami, podejmują odpowiedzialność za przygotowaną dla nich ofertę i twórczo ją współtworzą. Zbiorowy wysiłek powoduje, że wyjazd lub wyjście jest przez grupę doceniony i lepiej odbierany.

\section{Mobilna edukacja}

Jedną z najważniejszych funkcji Facebooka w mojej pracy ze studentami jest jego funkcja edukacyjna. Kiedy studiowałem w latach 90., wykładowca czytał przez 10 minut listę lektur na następne zajęcia, studenci notowali, a następnie udawali się do biblioteki, aby pożyczyć jedną bądź kilka pozycji. Dla większości książek nie starczało. W grupie facebookowej sam zamieszczam listę zagadnień i lektur, a ponadto linki, artykuły, książki (z poszanowaniem prawa autorskiego), wskazuję też na źródła materiałów w cyfrowych bibliotekach. Sporo w tej materii ułatwiają wolne licencje oraz coraz szersza digitalizacja zbiorów. Można dzielić się swoimi tekstami. Grupa staje się swoistym repozytorium cyfrowym, gdzie każdy ma dostęp do materiałów w dowolnym momencie i miejscu. Może je czytać, jadąc na uczelnię, stojąc w korku, może odwoływać się do nich w trakcie zajęć. Staram się ograniczyć proceder kserowania na potęgę, $\mathrm{z}$ którego potem niewiele wynika. Facebook demokratyzuje zatem proces uczenia się.

Na marginesie moich rozważań chciałbym wskazać ciekawy problem. Mimo że zamieszczam gotowy tekst na forum grupy, to przy pierwszym podejściu połowa studentów nie przygotowuje się do zajęć. Skoro nie mają ksero, tekstu również nie ma. Dopiero po zastosowaniu dziewiętnastowiecznych mechanizmów o charakterze behawioralnym, czyli sprawdzeniu znajomości tekstów podczas kolokwium, następuje zrozumienie idei funkcjonowania grupy w tej materii. Następuje gotowość do cyfrowego przyswajania materiału. Dużo żywiej i energiczniej studenci dyskutują nad tekstami zamieszczonymi w grupie facebookowej; potem dyskusja nad nimi może być kontynuowana i rozwijana już na forum grupy. W ogóle studencka grupa facebookowa jest znakomitym miejscem dyskusji, ale bardzo krótkiej, dopełniającej czy uzupełniającej albo zagajającej pod kątem zajęć lub zlecanych zadań. Na koniec semestru można również ocenić poziom zaangażowania na 
Facebooku, kultury dyskusji, sposobu prowadzenia rozmów, wspierania grupy i zaangażowania w proces zdobywania wiedzy i umiejętności.

Co roku organizuję specjalny wykład dla studentów, podczas którego puszczam film o tematyce związanej z wykładem. Staram się dać studentom możliwość wyboru filmu, proponując trzy lub cztery tytuły i urządzając głosowanie. Nierzadko moje sugestie mijają się z ich oczekiwaniami, albo znajduje się student czy studentka, którzy za pomocą argumentów przekonują resztę grupy, żeby obejrzeć ten lub inny film. I wygrywają głosowanie. Szanuję ich decyzje i wybory.

$\mathrm{Na}$ forum grupy zamieszczam informacje o planowanych kolokwiach, egzaminach, zakresie materiału do opanowania bądź przygotowania. Można monitorować frekwencję i aktualne oceny poprzez regularne zamieszczanie odpowiednich tabel, oczywiście z poszanowaniem zasad anonimowości. Za pośrednictwem tabeli w Excelu studenci mogą dokonywać symulacji swoich ocen. Dzięki temu nie czeka ich niespodzianka na koniec semestru czy roku. Mogą też weryfikować, czy w tabelę nie wkradł się błąd. Po przeprowadzeniu egzaminu pisemnego $\mathrm{z}$ reguły od razu go sprawdzam. Mówię studentom, że potrwa to około dwóch-trzech godzin i że się do nich odezwę. Studenci nie muszą czekać pod drzwiami. Kiedy skończę, od razu zamieszczam na Facebooku wyniki egzaminów, proszę też studentów o sprawdzenie, czy wszystko się zgadza. Facebook pozwala szybko weryfikować błędy.

\section{Podsumowanie}

Dobrym podsumowaniem niniejszych rozważań jest fragment z przytoczonego we wstępie artykułu naukowego na temat Facebooka: „Mimo że Facebook nie był pierwotnie przeznaczony do celów edukacyjnych, ma duży potencjał w zwiększaniu doświadczenia uczenia się (...). Facebook może promować modele uczenia się we współpracy, integrować studentów i wykładowców, zwiększać motywację do nauki i stworzyć bardziej komfortowy klimat w klasie. Ponadto Facebook może tworzyć silne społeczności na rzecz nauczania i uczenia się, które rozszerzają proces uczenia się w tradycyjnej klasie. (...) Ale powinniśmy pamiętać, że Facebook jest tylko narzędziem, które nigdy nie powinno zastąpić dobrej strategii nauczania" [Arteaga Sánchez, Cortijo, Javed 2014, s. 146].

Czy Facebook może stać się platformą edukacyjną? Sam w sobie pewnie nie. Nie jest też alternatywą dla prowadzenia zajęć czy spotykania się w uczelnianych budynkach. Jednak zwłaszcza w połączeniu z Messengerem jest ważnym narzędziem ułatwiającym i usprawniającym proces edukacji, staje się cennym dopełnieniem, przedłużeniem bądź rozwinięciem zajęć prowadzonych na uczelni.

Staram się twórczo wykorzystywać ten największy portal społecznościowy i widzę różnicę jakościową w pracy ze studentami, kiedy nie prowadziłem grup na Facebooku. Wstępne badania amerykańskich naukowców potwierdzają, że osoby, które przystąpiły do grupy facebookowej, w porównaniu do osób, które do niej 
nie przystąpiły, osiągają wyższe wyniki. Może się to wiązać z większym zaangażowaniem członków grupy, która tworzy „nową formę doświadczenia uczenia się poprzez współpracę" (new form of cooperative learning experience) [Bowman, Akcaoglu 2014, s. 23]. Zaangażowanie to może być rozbudzone poprzez nieustanny proces przekazywania informacji na Facebooku oraz demokratyzacji dostępu do nich. Zmniejszenie wysiłku (a więc i czasu) w zdobywanie informacji może być spożytkowane na proces uczenia czy wspólnych działań.

Po kilku latach doświadczeń mogę potwierdzić za Malwiną Popiołek [Popiołek 2015, s. 83], że Facebook przede wszystkim pozwala partycypować w procesie pozyskiwania informacji (w tym przypadku dotyczącej społeczności akademickiej), a jego najważniejszą funkcją jest funkcja informacyjna. Sprawny przepływ informacji umożliwia lepszą organizację procesu dydaktycznego, ułatwia rolę opiekuna roku, pozwala integrować studentów. Nie zgadzam się ze stwierdzeniem, że z powodu Facebooka studenci mogą podlegać umysłowej degradacji czy cyfrowej demencji, a on sam zastępuje im spotkania face-to-face [Spitzer 2013].

Wysyłanie e-maili do grup akademickich jest pozbawione emocji, interakcji. Warto dostrzec znaczenie, jakie może mieć Facebook we wzmacnianiu i pogłębianiu dotychczasowych - często obojętnych i powierzchownych - relacji ze studentami, ułatwianiu przekazywania i udostępniania wiedzy. Dzięki niemu może rozwijać się życie całego roku, toczyć dyskusja, mogą być kreowane i organizowane wydarzenia na rzecz studentów. Ważne jest wzajemne wspieranie się, dopingowanie, mobilizowanie, co jest możliwe poprzez wszelkiego rodzaju akcje, które można prowadzić z grupą studentów.

Facebook staje się elementem demokratyzacji edukacji, wzmacnia ją. Nazwałbym to solidarnościowym modelem edukacji czy modelem zarządzania humanistycznego grupą poprzez Facebooka. Taki model, ze względu na głęboki szacunek wobec jej członków, kształtuje wspólnotę w zakresie podejmowania decyzji, przeżywania i pamięci, poprawia funkcjonowanie studentów i wykładowców w świecie akademickim. Na plan pierwszy wysuwa się potrzeba zrozumienia osobistego doświadczenia członków grupy, formuje się wzajemna relacja oparta na dialogu [Kociatkiewicz, Kostera 2013, s. 11-13; Kostera, Szeluga-Romańska 2014, s. 20; Kreft 2015, s. 197-199].

W solidarnościowym, demokratycznym czy humanistycznym modelu jest jednak jedno ograniczenie. Facebook to tylko narzędzie i to od aktywności samego wykładowcy będzie zależeć intensyfikacja aktywności w grupie i poza nią, zwłaszcza w kontekście działań opiekuna roku. Na końcu odpowiedzialność za przygotowanie oferty, ostateczny kształt zajęć, wyjazdu i komunikacji ze studentami ponosi właśnie on - swoisty lider grupy. To wykładowca lub opiekun mobilizuje i zachęca grupę do działania, podejmuje za nią odpowiedzialność, a w momentach kryzysowych staje na wysokości zadania. 


\section{Bibliografia}

Arteaga Sánchez R., Cortijo V., Javed U. (2014), Students' Perceptions of Facebook for Academic Purposes, „Computers \& Education”, nr 70, s. 138-149.

Asterhan Ch.S.C., Rosenberg H. (2015), The Promise, Reality and Dilemmas of Secondary School Teacher-Student Interactions in Facebook: The Teacher Perspective, „Computers \& Education" nr 85, s. 134-148.

Bowman N.D., Akcaoglu M. (2014), “I See Smart People!”: Using Facebook to Supplement Cognitive and Affective Learning in the University Mass Lecture, „Internet and Higher Education", nr 23, s. 1-8.

Kociatkiewicz J., Kostera M. (2013), Zarządzanie humanistyczne. Zarys programu, „Problemy Zarządzania”, nr 4, s. 9-19.

Kostera M., Szeluga-Romańska M. (2014), Komunikowanie a humanistyczne aspekty roli profesjonalnej menedżera. Studium etnograficzne, „Zarządzanie Humanistyczne”, t. XV, z. 11, cz. III, s. 19-40.

Kreft J. (2015), Katalog zasad humanistycznego zarządzania mediami: próba definicji, [w:] B. Nierenberg, J. Kania, J. Kreft (red.), Zarządzanie humanistyczne, Wydawnictwo Uniwersytetu Jagiellońskiego, Kraków, s. 189-202.

Popiołek M. (2015), The Role of Facebook in the Process of Acquiring Information. Own Research Study, „Journal of Education Culture and Society”, nr 1, s. 75-85.

Rutka M. (2014), Czy Facebook może pełnić funkcję edukacyjna w podobny sposób, jak pełni funkcję reklamowo-marketingowa? Czy polscy uczniowie i nauczyciele sa na to otwarci i gotowi? [w:] G. Penkowska (red.), Fenomen Facebooka. Społeczne konteksty edukacji, Wydawnictwo Naukowe Katedra, Gdańsk.

Spitzer M. (2013), Cyfrowa demencja. W jaki sposób pozbawiamy rozumu siebie i swoje dzieci, tłum. A. Lipiński, Wydawnictwo Dobra Literatura, Słupsk. 